\title{
A System Dynamics Model for Wood-Based Renewable Energy Production from Degraded Land Rehabilitation
}

\author{
Budi Hadi Narendra ${ }^{1 *}$, Widiatmaka ${ }^{2}$, Cecep Kusmana ${ }^{3}$, \\ Lina Karlinasari ${ }^{4}$, Machfud $^{5}$ \\ ${ }^{1}$ Forest Research and Development Center, Ministry of Environment and Forestry, \\ Jl. Gunung Batu no.5 Bogor 16610, Indonesia \\ ${ }^{2}$ Department of Soil Science and Land Resources, Faculty of Agriculture, IPB University, \\ Jl. Raya Dramaga, Bogor 16680, Indonesia \\ ${ }^{3}$ Department of Silviculture, Faculty of Forestry, IPB University, Jl. Raya Dramaga, Bogor 16680, Indonesia \\ ${ }^{4}$ Department of Forest Products, Faculty of Forestry, IPB University, Jl. Raya Dramaga, Bogor 16680, Indonesia \\ ${ }^{5}$ Department of Agro-Industrial Technology, Faculty of Agricultural Technology, IPB University, \\ Jl. Raya Dramaga, Bogor 16680, Indonesia
}

Received: 5 February 2021

Accepted: 27 April 2021

\begin{abstract}
The trend of using wood biomass as a renewable energy source must be supported by a more extensive feedstock through the utilization of degraded land. However, not all regions have information on land potential in the provision of wood biomass. This study aims to develop a system dynamic model that can describe the potential of wood biomass production from degraded land rehabilitation. The main steps include problem identification, mapping causal loop diagrams, integrating mathematical models in a stock and flow diagram, evaluating the model, and simulating the conditions in the next 20 years based on existing conditions and three alternatives of policies scenarios. The result showed that all scenarios able to reduce the degraded land area by $16 \%$. Energy wood plantations can reduce the number of unemployed by half of the simulated amount while applying a moderate, optimistic, or very optimistic scenario, the number of unemployed will only be a quarter left in 2040. The optimistic scenario was considered to be applied in the rehabilitation of degraded land. The expected goals must be supported by the use of superior seedlings and effective forestry extension by increasing the number of extension officers and extension assistants.
\end{abstract}

Keywords: wood biomass, degraded land, system dynamic, energy wood plantation

*e-mail: narendra17511@gmail.com 


\section{Introduction}

Indonesian energy consumption is still based mainly on fossil fuels [1], including electricity supply generated primarily from coal-fired power plants [2]. The presence has a significant influence on the surrounding environment and harms human health [3-4]. Lombok Island with the peak electricity consumption of $260 \mathrm{MW}$, has begun to reduce dependence on coal imported from other islands [5], and is trying develop the use of renewable energy from local-natural energy resources [6]. In this framework, woody biomass can be utilized as potential bioenergy to gradually replace the coal through cofiring technology [7]. Globally, this scheme has been accepted as an inexpensive, short-term option to substitute coal [8] with carbon-neutral fuel [9]. Cofiring application with a 1:1 ratio of coal and wood significantly reduced $\mathrm{CO}_{2}$ emissions from $915 \mathrm{~kg}$ to $403 \mathrm{~kg}$ for every $1 \mathrm{MWh}$ of electricity production, without much change in the efficiency [10].

Communities in the East Lombok District traditionally use woody biomass more than in other parts of Lombok Island [11], mainly for household and small-scale industries [12]. Suppose wood biomass is to be used as a material for cofiring, it must be supported by developing woody biomass plantation in degraded land [13]. Spatial analysis showed that East Lombok District has 8,443 ha of degraded land suitable for the development of woody biomass plantations [14].

Sustainable plantation development should be supported by a complex understanding and attention to the relationship between ecological, economic, and social dimensions in a system dynamics approach [15]. In this study, the system simulates a complicated relationship [16] between rehabilitation of degraded land with the potential for energy wood production. A system dynamics modeling describes nonlinear relationships and represents complex systems by analyzing their dynamic behavior over time [17]. By running a simulation, the system is able to evaluate various policy scenarios [18] and show the possible unexpected results [19]. It is important for decision-makers to see the long-term results [20] and to prevent errors in determining conclusions [21] supported by a computer program facilitating the modeling [22].

Several studies on the dynamics of renewable energy supply have used system dynamics modeling [2328], however has never been done on the provision of wood biomass supply from degraded land rehabilitation activities. Therefore, this study aims to develop a system dynamic model that can describe the potential for wood biomass production from degraded land rehabilitation in East Lombok. The simulation results from the model will be considered in the direction of priority for degraded land rehabilitation.

\section{Methodology}

This study will build a system dynamics model that can simulate energy wood production from degraded land rehabilitation activities. In building a system dynamics model, the main steps include problem identification by identifying existing problems along with each variable and its feedback iteration. The next step was mapping causal loop diagrams, integrating mathematical models in a stock and flow diagram, simulating and evaluating the model, and running the scenarios $[20,29]$.

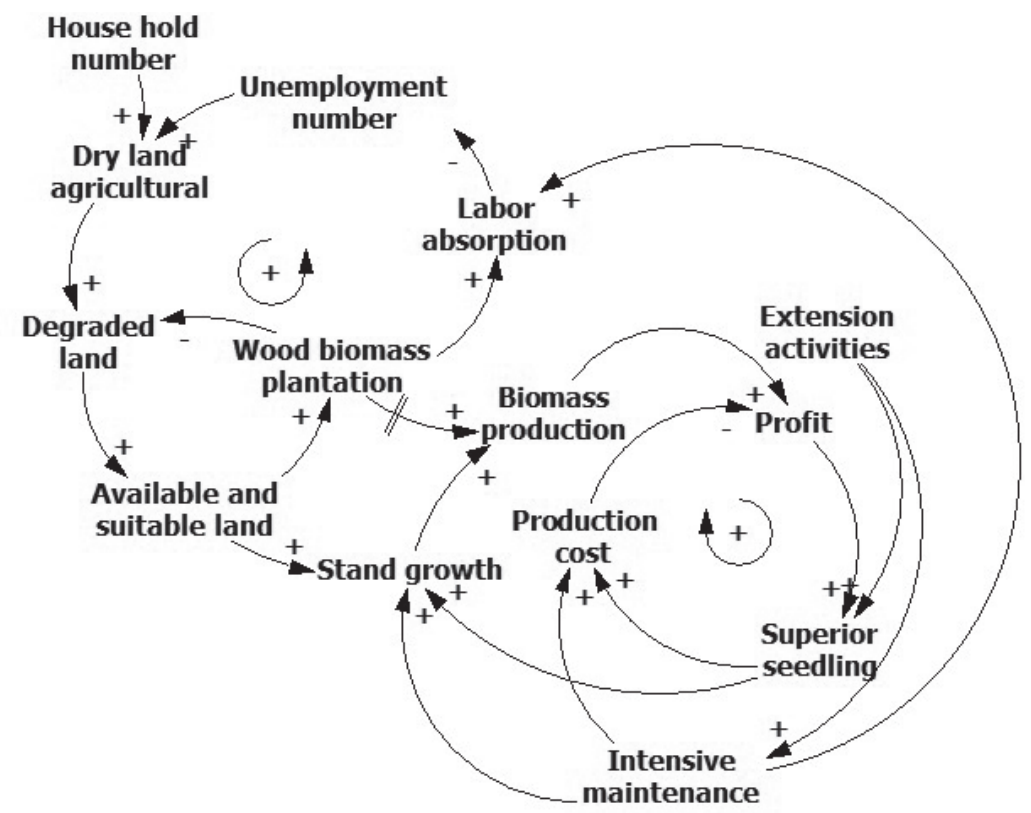

Fig. 1. The causal loop diagram of energy wood production. 


\section{Problem Identification}

This stage includes identifying existing problems and bordering the system to be studied by determining important and relevant variables in overcoming problems, achieving the objective, and designing policies. This stage was carried out through field observations, literature reviews, historical and statistical records, and discussions with experts [30]. The objective of the system approach in this study is to obtain an overview of the impact of using degraded land in producing wood biomass and the variables that influence it. The verbal description below will show clearly the relationship within and between the subsystems in the model.

In the biophysical subsystem, the existing condition shows that the increase of the degraded land area is mainly due to the extensification of dryland agriculture that does not follow soil conservation principles. Community involvement is needed to support the success of degraded land rehabilitation activities. This can be done by choosing a land rehabilitation scheme through an energy wood plantation development. This scheme is not only useful in supporting the reduction of degraded land, but also motivated the farmer community to improve welfare through profitability and demand of energy wood and support the acceleration of renewable energy use. The potential utilization of degraded land as wood biomass plantation depends on the availability of the land. The available land consists of different suitability classes, which also affect the tree growth in the plantations.

In the social subsystem, increasing unemployment, accompanied by new households' growth, will increase the rate of new dryland agriculture areas, which risks increasing the area of degraded land. The development of the wood biomass plantations potentially decreases unemployment. In addition to labor absorption, from an economic subsystem, increasing the area of wood biomass plantation will increase wood biomass supply and improve the people's income. The faster the stands grow, the greater the wood biomass produced. The growth can be promoted through the use of superior planting materials and apply intensive maintenance. Although results in a higher production cost increase, wood sales can cover the cost. Forestry extension officers play an essential role in encouraging farmers to use superior seedlings and do intensive maintenance. However, the availability of superior seedlings needs to be handled by the Government because of the limitations of farmers in accessing superior plant genetic resources.

\section{Causal Loop Diagram}

The next step in system dynamics modeling is to arrange relationships between variables and build the feedback loop in a structured form of a causal loop diagram [17]. The diagram, showing the problems and the relationship between the variables involved, was described to limit the system to be studied [31]. The diagram showed in Fig. 1 is used to understand the system behavior, which will assist in the formation of dynamic models. The diagram depicts the causal variables significant in a system and is linked using arrows to the effect variable. The relationship between one variable and the next variable in a loop can be either positive or negative. A positive relationship shows that if a variable value increases, the other affected variables will also increase. The opposite condition occurs in a negative loop.

\section{Stock Flow Diagram}

Based on this causal relationship, technical analysis was carried out by making a stock-flow diagram (SFD) that describes a model's structure. The SFD structure describes the model variables for the accumulation process and the flow of information and material in the system [20]. SFD is more often set up after CLD has formed. The component of SFD as shown in Figure 2 , includes stock variables, flow variables, additional variables, and connectors. Stock shows the status or condition of a system, while the flow is a change based on decisions according to system conditions [30, 32].

The SFD shown in Fig. 2 indicates several variables resulted from the final calculation, e.g. remaining unemployment, planted area, degraded land area (after planting), harvested area, wood production, and profit per ha. The others are the variables that are required in the calculations. Mathematical equations that show the relationship between variables were integrated into the model structure based on the data and information available in the study area. Table 1 contains the main mathematical equations used in the model.

Not all of the degraded land area is available and suitable for the development of energy wood plantations. The available degraded land areas with conformity levels of S1 (very suitable), S2 (quite suitable), and S3 (less suitable) become scenarios based on the degraded land map that has been resulted in previous research [14]. The profit earned from the existence of energy wood plantations is assumed to come only from wood production. The yield from each hectare of energy wood plantation concession was calculated based on the selling value of energy wood reduced by costs that may arise in managing the energy plantation, including the cost of seeds, planting, maintenance, and harvesting. Seedling and maintenance costs will be further regulated in the simulation scenario. The model was simulated to study the behavior in describing the symptoms or processes that occur in the system.

\section{Model Evaluation}

Model evaluation was done to build trust in the system dynamic model. At this stage, two things that are important to do are compare the structure of 


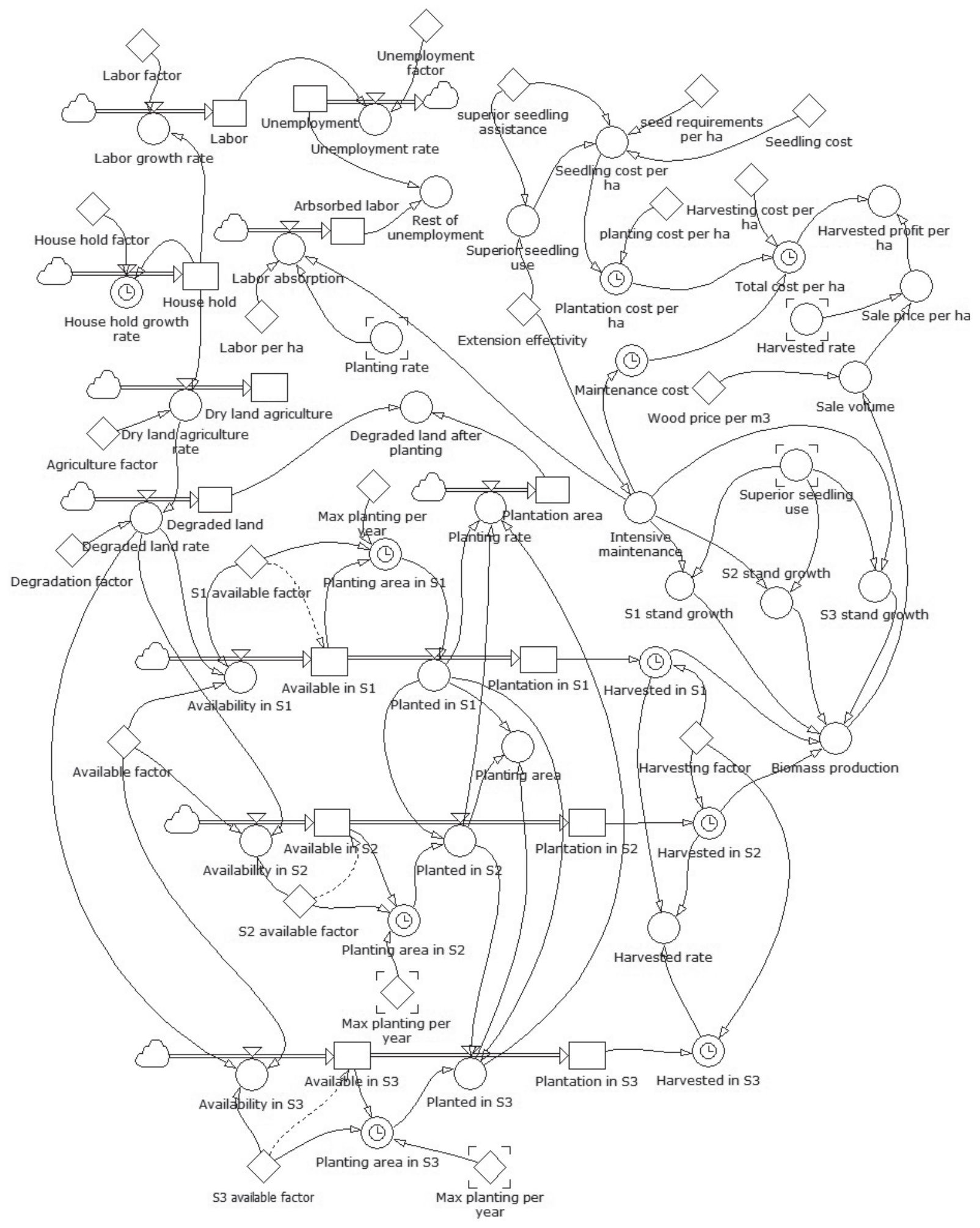

Fig. 2. Stock flow diagram.

the model with real conditions, and validate the model's behavior by comparing the results of model simulations to real conditions. The simulation results were validated so that the model can be used further [33], and it makes sure that the model was based on observations and real system data [17, 34]. In an evaluation, data availability is not the only important thing in building a good model. The model structure test was carried out by analyzing the logical level of the built structure and the resulting output behavior, while the model performance validation was analyzed based on simulation results with available historical data series [34].

Based on the SFD, the simulation model has been run on the Powersim Studio 10 software with data 
Table 1. Main equations used in the model.

\begin{tabular}{|c|c|}
\hline Variable & Equation \\
\hline Biomass production & 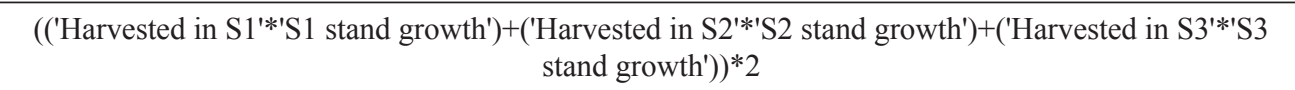 \\
\hline Harvested profit per ha & 'Sale price per ha'-'Total cost per ha' \\
\hline Harvested rate & 'Harvested in S1'+'Harvested in S2'+'Harvested in S3' \\
\hline Labor absorption & IF('Intensive maintenance' $=0$,('Planting rate'*'Labor per ha'), 'Planting rate'*0.45) \\
\hline Maintenance cost & IF (TIME>2020,2450000*'Intensive maintenance', 0) \\
\hline Plantation cost per ha & IF(TIME>2019, ('Seedling cost per ha'+'planting cost per ha'), 0) \\
\hline Planting area & 'Planted in S1'+'Planted in S2'+'Planted in S3' \\
\hline S1 stand growth & $39+($ 'Superior seedling use'*39*0.39)+('Intensive maintenance'*39*0.35) \\
\hline S2 stand growth & $\left(39+\left(\right.\right.$ 'Superior seedling use $\left.{ }^{*} 39 * 0.39\right)+($ 'Intensive maintenance'*39*0.35) $) * 0.8$ \\
\hline S3 stand growth & $\left(39+\left(\right.\right.$ 'Superior seedling use $\left.{ }^{*} 39 * 0.39\right)+($ 'Intensive maintenance'*39*0.35) $) * 0.6$ \\
\hline Sale volume & 'Biomass production'*'Wood price per $\mathrm{m}^{31}$ \\
\hline Seedling cost per ha & $\begin{array}{c}\text { IF ('superior seedling assistance' }=1,0, \mathrm{IF}(\text { 'Superior seedling use' }=0 \text {, ('Seedling cost'*'seed requirements } \\
\text { per ha'), }\left(2.7^{*} \text { 'Seedling cost'*'seed requirements per ha'))) }\right.\end{array}$ \\
\hline Total cost per ha & 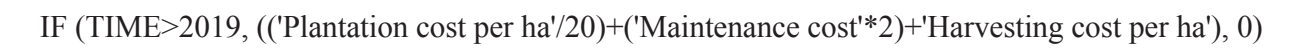 \\
\hline Degraded land rate & 'Dryland agriculture rate'*'Degradation factor' \\
\hline Household growth rate & IF (TIME<2010,'House hold'*'Household factor', 'House hold'*0.0095) \\
\hline Planting area in $\mathrm{S} 1$ & $\begin{array}{c}\text { IF (TIME }<2020,0,(\text { IF ('Available in S1'<'Max planting per year','Available in S1','Max planting per } \\
\text { year'*'S1 available factor'))) }\end{array}$ \\
\hline Planting area in S2 & $\begin{array}{c}\text { IF (TIME<2020,0,(IF ('Available in S2'<'Max planting per year','Available in S2',('Max planting per } \\
\text { year'*'S2 available factor')))) }\end{array}$ \\
\hline Planting area in $\mathrm{S} 3$ & $\begin{array}{c}\text { IF (TIME<2020,0,(IF ('Available in S3'<'Max planting per year','Available in S3',('Max planting per } \\
\text { year'*'S3 available factor'))) }\end{array}$ \\
\hline Superior seedling use & IF('superior seedling assistance'=1, 'superior seedling assistance', IF ('Extension effectivity'=2, 1, 0)) \\
\hline
\end{tabular}

input for the years 2008 - 2017. The simulation results were evaluated to see the trend and involved factors by validating the model's structures. Simulations were carried out with the initial assumption that the increase in degraded land was in line with land clearing for dry agriculture due to the rise in households' number. The households' rate growth was simulated according to the existing trend. In 2008, the number of households in East Lombok was 291,821 households, and it increased to 347,122 in 2017 . With an average household growth of $2.3 \%$ per year, it is projected that by 2040 the number of households will reach 604,139 households assuming constant growth of $2.3 \%$ per year. An increase in the number of families will have implications for increased land use for dryland agriculture by $0.2 \%$ per year, based on trend data on the household number with a profession as farmers and changes in the dryland agricultural area.

Based on the structure's social subsystem, an increase in household number has implications for increasing the workforce. However, not all of this workforce is absorbed by domestic formal employment resulting in unemployment and migrant workers. Even though the number tends to decrease, in 2017 the number of unemployed still reached 27,059 people from the initial 34,500 people in 2008 .

The development of energy wood plantations, especially in intensive maintenance, is expected to accelerate the unemployment reduction rate to near zero by 2040. Based on Statistics Indonesia data, unemployment tends to decline even though in certain years there is an increase in data that can be caused by fluctuations in the number of migrant workers due to government policy changes. In this modeling, the reduction rate of unemployment was calculated based on the unemployment factor of $0.12 \%$ from the total workforce and is assumed to be constant. The workforce absorption will reduce unemployment due to the development of energy wood plantations.

In this study, the absorbed workforce was assumed to remain constant during the simulation period, which is 0.3 people per hectare. In other words, the development of 3 ha of the energy wood plantation will absorb one worker. Suppose intensive maintenance is applied as is usually carried out in industrial plantation forest companies. In that case, the workforce absorption reaches 0.45 people per ha, or one person is absorbed in developing 2 ha of energy wood plantations [35]. 
The effectiveness of forestry extension activities strongly influences the application of intensive maintenance by farmers. However, the obstacle in East Lombok is the limited number of forestry extension officers. Even the number tends to decrease because some have entered retirement age and some are approaching retirement age. Effective extension services are also able to encourage farmers to use superior seedlings. However, the seed must be bought at a higher price (about three times the cost of ordinary sources) but will result in higher growth

In the biophysical subsystem, an evaluation of the model structure can be illustrated that the simulated planting of energy wood plantations was begun in 2020, then continued gradually every year. From the available and suitable degraded land for energy wood plantation, planting was assumed to be carried out gradually with a limit of 2,800 ha per year. According to the maximum planting area data that East Lombok Regency has achieved, this limit indicates the maximum area that can be planted per year. In the model structure, restrictions have been made that planted area in a year will not exceed the limit. Also, the total area of degraded land will not exceed the land area in East Lombok Regency (160 thousand ha). The area of degraded land available for energy plantations will also not exceed the area permitted for the development of energy wood plantations, based on spatial planning regulation. The model structure has been arranged to prioritize degraded land with an S1 suitability level (very suitable). After all, S1 lands are planted, proceed to the land with S2 suitability (moderately suitable).

In this study, the energy wood species used were Calliandra, Leucaena, Gliricidia, and Acacia. They are legume families with relatively the same stand growth and biomass production so that in this modeling, it is assumed that they have the same biomass increment and output. Planting is carried out at a tight distance of $1 \times 1 \mathrm{~m}^{2}$ [36] so that 10,000 seedlings are needed for each hectare. Assumptions used in planting are all seedlings in good condition, planted at the beginning of the rainy season, and they grow well until the harvest period. Planting with a tighter spacing can be done up to $1 \times 0.25 \mathrm{~m} 2$ but tends to produce larger leaf biomass with smaller stem diameter, so it is feared that it will not qualify as fuel for power plant. Also, using tighter spacing will require a larger number of seedlings and make maintenance activities difficult. Simultaneously, the wood biomass produced is not much different from the spacing of $1 \times 1 \mathrm{~m}^{2}$ [37].

The common management of the energy wood plantation is carried out using a coppice system in which the harvested stands will grow back to produce several new shoots on each stump. Timber harvesting is carried out on stands that are two years old. The new shoots are nurtured, and two stalks are left for each stump and will be harvested again after the shoot reaches two years old. And so on, a biennial harvest cycle is carried out until the stand comes 20 years of age
$[38,39]$, and new seedlings should be planted, although certain species can reach a 30 -year cycle [40]. In this modeling, plant productivity in producing energy wood was assumed to be constant, although many studies have shown that planting with legumes can improve soil fertility, mainly through increasing the soil carbon and nitrogen elements [41, 42].

The production (volume) of woody biomass resulting from harvesting in a particular area was modeled by multiplying the tree's growth per year) by the age (two years). The optimal plant increment rate of $39 \mathrm{~m}^{3}$ ha $^{-1}$ year ${ }^{-1}$ was obtained from field observations for the four tree species, both those grown in Lombok [43, 44] and other similar locations such as in Flores [45], Bali [46, 47], Java, and Madura [44]. Each land was assumed to produce optimum biomass, where the wood products in the S1 suitability class can reach $100 \%$ of the optimal output, $80 \%$ for S2 suitable land, and $60 \%$ for S3 suitable land [48, 49]. Application of intensive maintenance potentially increases the stand growth by $39 \%$. The use of superior seedling probably increases the growth rate by $35 \%$ and can reach up to $75 \%$ [37, 50-52]. Both efforts will become scenarios in the next stage according to the potential for degraded land.

The evaluation of model behavior is carried out to complement the structural evaluation results. This evaluation was shown, among others, through the value of the mean absolute percentage error (MAPE), which indicates the absolute mean deviation between the simulation results against the actual (historical) value with an acceptable deviation less than $<10 \%$ $[53,54]$. MAPE is one of the most popular indicators in the assessment of prediction accuracy due to scaleindependent and easy to interpret [55], and defined as equation 1 [56].

$$
\text { MAPE }=\frac{\mathbf{1}}{\mathbf{N}} \sum_{\mathbf{t}=\mathbf{1}}^{\mathbf{N}}\left|\frac{\mathbf{A}_{\mathbf{t}}-\mathbf{F}_{\mathbf{t}}}{\mathbf{A}_{\mathbf{t}}}\right| \times 100 \%
$$

...where: $\mathrm{A}_{t}$ and $\mathrm{F}_{\mathrm{t}}$ denote the actual and simulation values at data point $t$, respectively; $\mathrm{N}=$ number of data points.

A performance validation test follows the simulation results to obtain confidence performance. It qualifies as a scientific model and the behavior of the output model following empirical data's behavior. Statistical tests can identify deviation from the model output with empirical data [31]. Model performance validation is analyzed based on simulation results with available historical data series [34]. In this study due to limitations of historical data series, the confirmation was carried out only on households, labor force, and unemployed numbers for 2008 - 2017 historical data. The results of MAPE calculation for the variable household number, labor force, and unemployment are $0.3 \%, 0.2 \%$, and $1.6 \%$, respectively. The validation results on the three variables indicate that the MAPE values are smaller than $10 \%$, indicating that the model has a good performance and can be accepted scientifically. 


\section{Scenario Planning and Running the Model}

Models that have been evaluated will be used for scenario planning and modeling. The scenarios were structured as a model intervention that has been built to support the achievement of model objectives. Scenarios were designed to combine several simulated factors from controlled inputs as parts of the leverage factors for sustainability. The scenarios to be applied were the result of expert discussion by considering the future applicability. The results of scenario planning were used to explore different conditions that may occur in the future. The results can be considered by decisionmakers in determining policies, while still paying attention to the assumptions and model boundary [57].

Four scenarios have been formulated in this study, namely the existing (business as usual), moderate, optimistic, and very optimistic scenarios. The existing scenario describes the current actual condition for the forestry extension activities that are not yet effective, and farmers do not use superior seeds in developing energy wood plantations. In this scenario, the allocation of degraded land area to be developed for energy wood plantations follows the results of land suitability analysis using the FLOWA method, namely with a neutral optimism level $(\alpha=1)$ and an error risk level at a medium level $(0.5)$. In this allocation, the very suitable (S1) area covers $76 \%$ of the degraded land area, and its use will be prioritized first, then followed by planting in suitable degraded land (S2) with an area of $24 \%$ of the degraded land [14].

In the moderate scenario, the allocation of critical land area to be developed is still the same as the existing scenario. There was a change in the effectiveness of extension. With the increase in the effectiveness of extension services, it is assumed that farmers can implement intensive plant maintenance and use the superior plant seedlings obtained independently by their effort.

In the optimistic scenario, the conditions for land allocation and extension effectiveness were the same as in the moderate scenario, except that the use of superior seeds was not carried out independently by farmers. Still, there was the assistance of superior seeds from the Government, which was assumed to meet all farmers' needs. The existence of superior seed assistance, which is one of the most significant cost components in developing energy wood plantations, can reduce the production costs incurred by farmers to increase the benefits obtained.

The very optimistic scenario was characterized by land allocation used at the extreme optimism level. In this allocation, all available critical land areas were assumed to have S1 suitability (very suitable) but with a very large error risk level. The high level of risk is due to a land unit's suitability was determined by at least one suitability criterion being met. This condition is ecologically complicated to fulfill by biophysical conditions (climate and soil) in the field. At this level of decision, it is not stated what minimum criteria must be met to produce a very suitable level of suitability.

Analysis of land suitability for the use of a species or group of plant species will be very suitable if more criteria are met based on the plant's growth requirements. Based on this, it would be more realistic if the decision on suitability for a particular plant species was based on more criteria [58]. In this dynamic modeling, the use of a very optimistic scenario involving $100 \%$ land suitability allocation is carried out to determine the maximum output (at the extreme level) that this dynamic model can achieve.

The scenarios prepared as controlled inputs are expected to be capable to support the sustainability of energy wood plantations. The design and combination of several factors in the scenarios were run in the model. The analyzed output includes the quantitative achievement of each formulated goal, includes the reduction area of degraded land through increasing the area of energy wood plantations, decreasing the number of unemployed through the amount of worker absorbed in the energy wood plantation, the amount of energy wood produced, and increasing community income through profits from selling energy wood obtained.

\section{Results and Discussion}

\section{Energy Wood Plantation Area}

Based on the scenario simulations, the planting of energy wood plantations will reduce degraded land area, as shown in Fig. 3. Degraded land in East Lombok, which is predicted to cover 59,537 ha in 2020 and increase to 110,955 ha in 2040 , can be reduced to 93,678 ha (16\% decrease) if degraded land is rehabilitated into energy wood plantation. The rehabilitation with a side orientation to increase energy wood plantations cannot rehabilitate $100 \%$ of the degraded area due to not all of the degraded land is available to be rehabilitated into energy wood plantations. As a result of rehabilitation, the extent of energy wood plantation cumulatively increases from 2,800 ha in 2021 to 17,277 ha in 2040 . Among the scenarios, there is no difference in the area of energy wood plantations planted each year. The difference is only found in the composition area of the land suitability level.

\section{Labor Absorption}

The labor absorption in the development of energy wood plantations is directly proportional to the area cultivated. Fig. 3 shows the decrease in the number of unemployed compared to without energy plantations' development delivers an acceleration in the first four years. This is related to the large area of land planted in the first four years. Apart from being influenced by the land planted area, labor absorption is also determined by plant maintenance intensity. Without the 

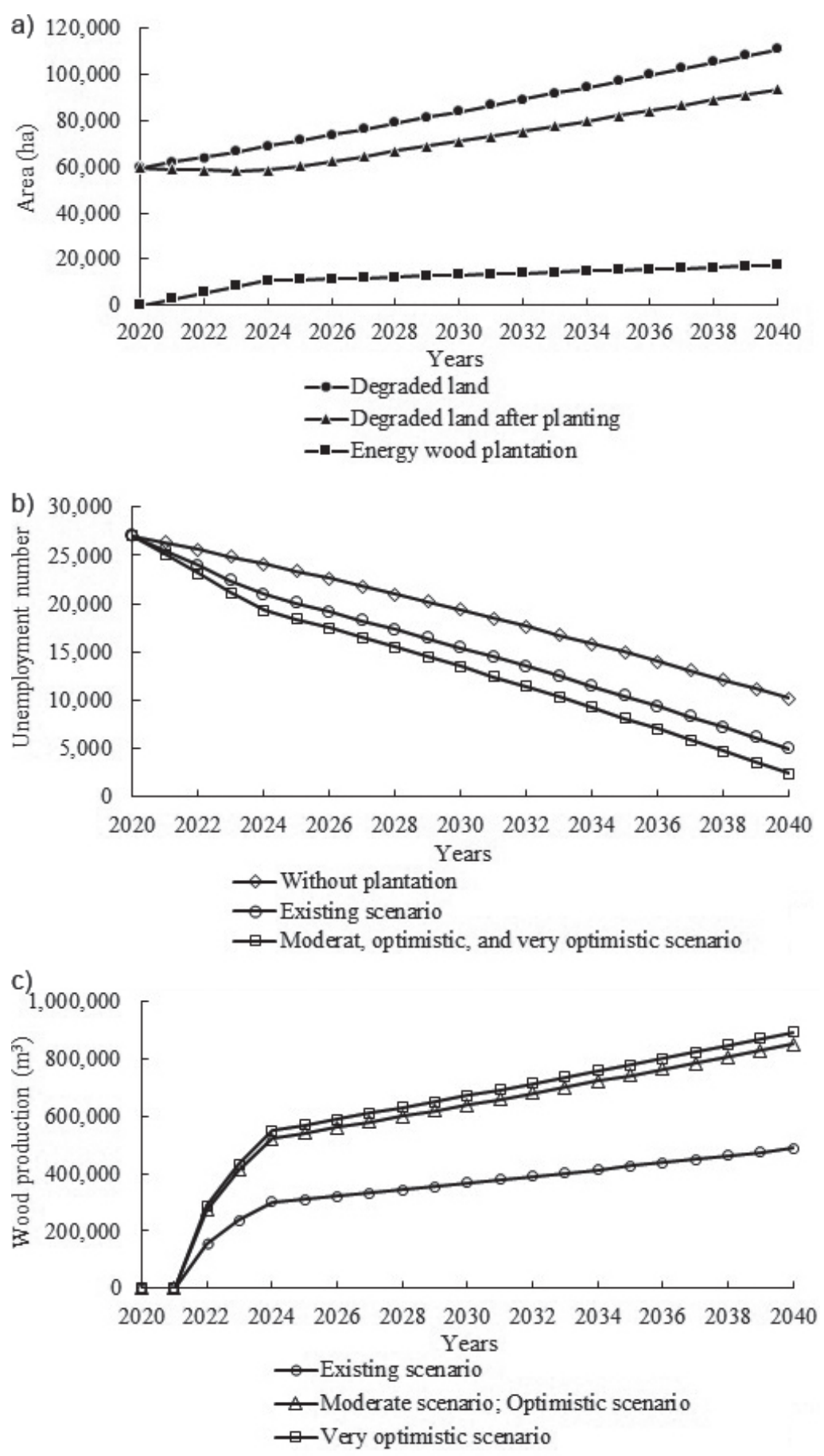

Fig. 3. Simulation results for degraded land and energy wood plantation area a), unemployment number b), and energy wood production c).

development of energy wood plantations, the number of unemployed people in 2040 is simulated to reach 10,197 people. With this development, the existing scenario will reduce the number of unemployed to 5,014 people, while by applying the other scenario, the number of unemployed will only be 2,422 people in 2040 . The existing scenario has a lower labor absorption because it does not apply intensive maintenance. The other scenarios apply intensive maintenance, resulting in the same reduction in unemployment.

\section{Energy Wood Production}

Two years after planting, in 2022 there will be the first harvest of energy wood trees. The 2,800 ha of planting area will produce $158,017 \mathrm{~m}^{3}$ energy wood in the existing scenario, $274,949 \mathrm{~m}^{3}$ for the moderate or optimistic scenario, and $288,812 \mathrm{~m}^{3}$ for the very optimistic scenario as shown in Fig. 3. The stands that have been harvested will sprout and will be harvested again in the next two years. As energy wood plantations 
increase through additional planting areas each year, energy wood production will also increase. In 2040 it was projected to produce $487,524 \mathrm{~m}^{3}, 848,291 \mathrm{~m}^{3}$, and $891,062 \mathrm{~m}^{3}$ for the existing, moderate or optimistic, and very optimistic scenarios, respectively.

A sharp increase in wood production in all scenarios in the first three years, and then this increase tends to slope. This is related to the large planting area at the beginning of the development of energy wood plantations. After the first four years of planting, the fifth year planting area only comes from the increasing area of degraded land in the previous year so that the increase in the area that can be harvested only slightly increases.

Fig. 3 shows a difference in the volume of wood production between scenarios even though the area harvested each year is the same. The difference in the tree growth was due to the use of superior seedlings and/or application of intensive maintenance. In the existing scenario, it is described that farmers do not use superior seedlings and do not carry out the intensive maintenance of their plants. This is partly due to the lack of intensive counseling and the absence of superior seedlings. In this condition, stand increment is assumed to be 39,31 , and $23 \mathrm{~m}^{3}$ ha $^{-1}$ year ${ }^{-1}$ on $\mathrm{S} 1, \mathrm{~S} 2$, and $\mathrm{S} 3$ land suitability, respectively. The existence of effective extension as assumed in the moderate, optimistic, and very optimistic scenario will encourage farmers to use superior seedlings and carry out intensive maintenance resulting in higher tree growth [59] to 68,54 , and $41 \mathrm{~m}^{3} \mathrm{ha}^{-1}$ year $^{-1}$ on the S1, S2, and S3 land suitability, respectively. The maximum increment that can be obtained is equivalent to the result obtained in Leucaena growth that was equivalent to $64 \mathrm{~m}^{3} \mathrm{ha}^{-1}$ year ${ }^{-1}$ in medium soil fertility conditions, accompanied by NPK fertilization of $250 \mathrm{~kg} \mathrm{ha}^{-1} \mathrm{year}^{-1}$ and the use of the superior Leucaena seed Taramba cultivar [37].
Compared to the moderate and optimistic scenario, there is a slight increase in production in the very optimistic scenario because, in the very optimistic scenario, the S1 land allocation reaches $100 \%$, so that all stands are assumed to be able to reach an increment of $68 \mathrm{~m}^{3} \mathrm{ha}^{-1}$ year $^{-1}$. In the moderate and optimistic scenario, the land allocation for $\mathrm{S} 1$ reaches $76 \%$, and the remaining $24 \%$ was for S2 land so that this $24 \%$ difference results in differences in wood production.

The comparisons of the cost and sales income for 20 years in each scenario are presented in Fig. 4. The very optimistic scenario shows the highest sales-cost difference (IDR 14,726,000 ha $^{-1}$ year $^{-1}$ or $57 \%$ higher than the difference in the existing scenario (IDR $9,406,400 \mathrm{ha}^{-1}$ year $^{-1}$ ). The highest profit is obtained because the very optimistic scenario produces the highest product sales volume and the production costs are relatively the same as the production costs in the optimistic scenario, and lower than the moderate scenario. Although the existing scenario shows the lowest production costs (because it only uses random seeds and does not apply intensive maintenance), the sales value shows the lowest value.

\section{Potential of Electricity}

Based on the simulated annual wood production, its potential use as a renewable energy source can be calculated. The use of energy wood is very potential as fuel in biomass-based power plants. In East Lombok, electrical energy security is achieved by building new power plants, which are coal-fired steam power plants. If the potential for energy wood can be fulfilled from sustainable sources, its use will be more economical and environmentally friendly. The use of wood biomass as fuel for power plants to support energy security also supports East Lombok Regency's energy independence.

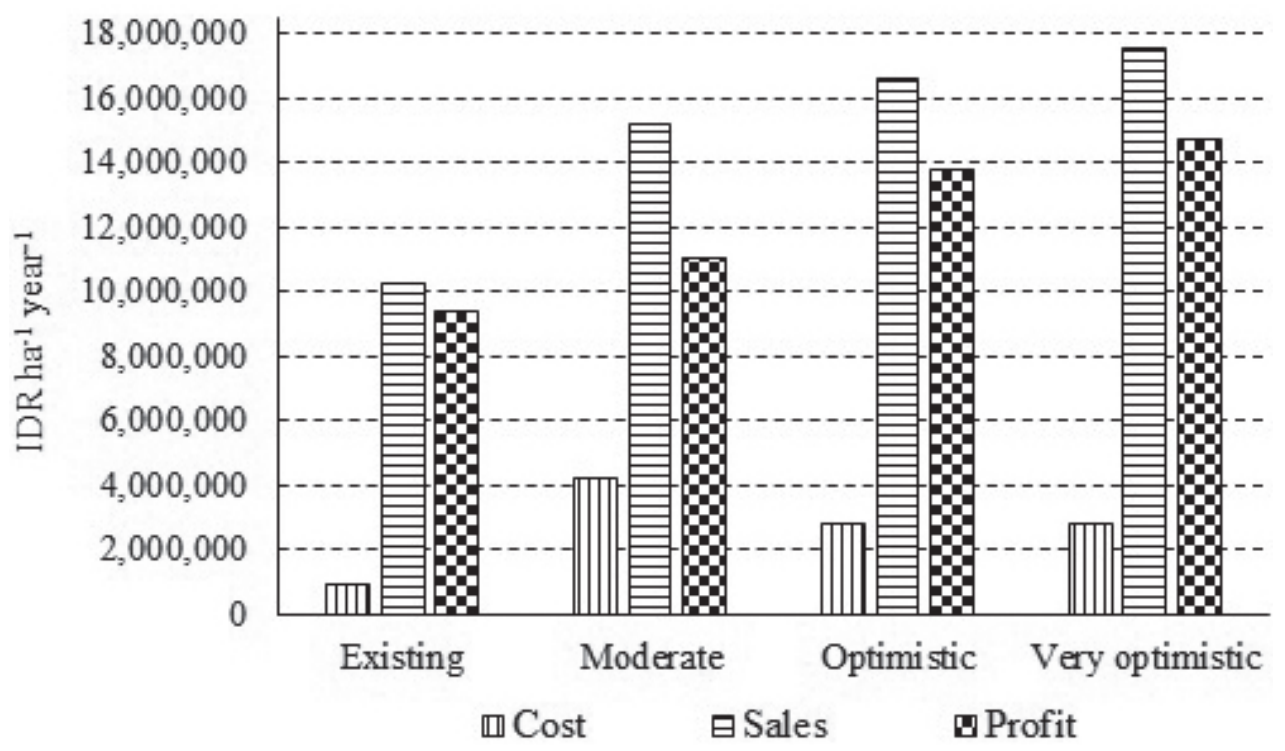

Fig. 4. Simulation results of average production costs, sales, and the difference in each scenario. 
Table 2. Electricity potential resulted on the early and last year simulation

\begin{tabular}{|c|c|c|c|c|c|}
\hline Scenario & $\begin{array}{l}\text { Wood weight } \\
\qquad\left(\mathrm{m}^{3}\right)^{\mathrm{a}}\end{array}$ & $\begin{array}{l}\text { Calorific value } \\
(\mathrm{x} 1.000 \mathrm{Kcal})^{\mathrm{b}}\end{array}$ & $\begin{array}{l}\text { Electricity potential } \\
(\mathrm{kWh})^{\mathrm{c}}\end{array}$ & $\begin{array}{c}\text { Potential } \\
\text { supplied household }^{\mathrm{d}}\end{array}$ & $\begin{array}{l}\text { Selling price } \\
(\mathrm{x} \text { IDR } 1,000)^{\mathrm{e}}\end{array}$ \\
\hline & \multicolumn{5}{|c|}{ Year 2022} \\
\hline Existing & 158,017 & $379,240,800$ & $154,369,968$ & 154,990 & $268,202,382$ \\
\hline Moderate & 274,949 & $659,877,600$ & $268,603,177$ & 269,682 & $466,671,160$ \\
\hline Optimistic & 274,949 & $659,877,600$ & $268,603,177$ & 269,682 & $466,671,160$ \\
\hline \multirow[t]{2}{*}{ Very optimistic } & 288,812 & $693,148,800$ & $282,146,219$ & 283,279 & $490,200,841$ \\
\hline & \multicolumn{5}{|c|}{ Year 2040} \\
\hline Existing & 487,524 & $1,170,057,600$ & $476,271,946$ & 478,185 & $827,474,879$ \\
\hline Moderate & 848,291 & $2,035,898,400$ & $828,712,444$ & 832,041 & $1,439,805,000$ \\
\hline Optimistic & 848,291 & $2,035,898,400$ & $828,712,444$ & 832,041 & $1,439,805,000$ \\
\hline Very optimistic & 891,062 & $2,138,548,800$ & $870,496,289$ & 873,992 & $1,512,400,253$ \\
\hline
\end{tabular}

${ }^{\mathrm{a} A v e r a g e}$ of wood density $=0.6 \mathrm{ton} / \mathrm{m}^{3}[60,61]$

${ }^{\mathrm{b}}$ Average of wood calorific $=4,000 \mathrm{Kcal} / \mathrm{kg}$ [62]

${ }^{c} 1 \mathrm{Kcal}=4,186.8$ Joule $=0.001163 \mathrm{kWh}$

Average of power plant machine eficiency $=35 \%[63,64]$

Electricity $=$ calorific value $(\mathrm{Kcal}) \mathrm{x}$ power plant machine eficiency $\mathrm{x} 0.001163$

${ }^{\mathrm{d} A v e r a g e}$ of annual electricity consumption per household $=996 \mathrm{kWh}$ [1]

ePrincipal cost of electricity generation in Lombok area based on ministerial decree $=$ IDR $2,044 / \mathrm{kWh}$

Maximum purchase price from electricity producer to State Electricity Company based on ministerial regulation $=85 \% \mathrm{x}$ principal cost

Selling price $=$ Electricity potential $(\mathrm{kWh}) \times$ principal cost $(\mathrm{Rp} / \mathrm{kWh}) \times 85 \%$

If the district uses coal as the fuel of the power plant, East Lombok will depend on coal supply from other islands. The energy wood plantation potentially meets the needs of power plant fuel. East Lombok District has the sovereignty to determine the source of its electrical energy from potential local land resources.

The potential for electrical energy that can be generated through the use of energy wood production is presented in Table 2. Based on data from Statistic Indonesia, currently, $74.3 \%$ of households in East Lombok have received electricity from the State Electricity Company. Table 2 shows the potential number of households served by electricity from the wood-based power plant is 154,990 households or $45 \%$ of East Lombok's current population [1].

In 2040, the number of households served by PLN electricity using wood biomass fuel in the optimistic scenario will reach 832,041 households. In that year, the number of households in East Lombok is predicted to reach 352,566 households. There will be a surplus of electrical energy for households, assuming constant household growth, $900 \mathrm{Wh}$ of electricity needs for each household, and electricity use are only calculated for household needs without considering the requirements for industry, services, tourism, and others.

On a broader scale, the use of degraded land for energy wood production will be able to generate greater electrical energy. The development of electricity from renewable sources is not only carried out on large-scale energy sources such as geothermal and hydropower, but also small and medium scale generators such as small- scale biomass-based power plants. This small-scale power plant is suitable for developing remote islands or areas that still use fossil fuel power plants. The Government encouraged the development of biomassbased power plants through the issuance of Ministerial Regulation which regulates the mechanism and tariffs for purchasing electricity from biomass-based power plants. Although the selling price of electricity from coal-fired power plants is lower than from wood biomass, with the negative impact on the environment caused by coal use, it is necessary to consider the amount of environmental impact value in the selling price of electricity.

Apart from being sourced from biomass, the fulfillment of electricity from renewable sources can also come from solar power plants. However, its development often faces obstacles in the form of high initial investment, and the price of electricity generated is relatively higher because the subsystem needs are still dependent on imported products [65]. Also, the development of solar power does not directly contribute to efforts to handle degraded land.

\section{Discussion}

A study on the potential use of degraded land in East Java and West Java shows that as a wood biomass provider for power generation, degraded land in these two provinces of Indonesia will cope with the electricity of 4.2 million households [44]. Biomass power plants on a large scale are run by a combustion process using 
thermal conversion. The efficiency increase from a simple Rankine cycle of only $37 \%$, using a regenerative turbine system can increase to $50 \%$. The larger the power plant's scale, the more efficient the electrical energy is produced [66].

Research on a power plant with a capacity of 6.3 MW in West Kalimantan has resulted in the values of the energy cost (the cost to generate electricity per $\mathrm{kWh}$ ) of several alternative fuels uses. The use of wood as fuel showed the lowest price of energy at the rate IDR 443 per $\mathrm{kWh}$, followed by oil palm shells IDR 518 per $\mathrm{kWh}$, and coal IDR 898 per $\mathrm{kWh}$, while the use of a mixture of coal and wood (30:70) as used today is worth IDR 751 per kWh [67]. The use of wood biomass as an energy source has been growing, especially in European countries where $30 \%$ of energy consumption comes from biomass, which is higher than the $9 \%$ consumption of biomass for world energy [68].

In the development of energy wood plantations, the use of superior seedlings should have met the physicalphysiological quality standards. The assessment includes health, height and diameter of stems, compactness of the media, and a number of leaves, as well as the source of plant material (seeds) that meet genetic quality standards based on the classification of certified seed sources. The genetic quality of the planted seeds is the primary genetic structure that is inherited that determines the offspring's appearance. If the genetic quality is bad, the appearance that appears will be bad and is not influenced by the environment and silvicultural efforts. On the other hand, if the inherited genetic potential is good, this potential will emerge through appropriate silviculture [69].

The provision of superior seedlings has become one of the demands in increasing plantation forest productivity, community plantation forests, community forests, and forest rehabilitation activities. The use of superior seedlings accompanied by silvicultural techniques is an essential effort in increasing forest productivity. To support a large-scale energy wood plantation, farmers need the seed produced by superior stands resulted from tree breeding activities. The Centre for Forest Biotechnology and Tree Improvement of Indonesia is a research and development institution under the Ministry of Environment and Forestry, which has been an intensive program of breeding for energy wood species, especially Acacia, Calliandra, and Leucaena since 1996.

This program has produced superior seeds from the first generation (F1) for Calliandra callothyrsus with increment (growth) reaching $65 \mathrm{~m}^{3} \mathrm{ha}^{-1}$ year ${ }^{-1}$, and second-generation (F2) for Acacia auriculiformis with increment can reach $72 \mathrm{~m}^{3} \mathrm{ha}^{-1}$ year ${ }^{-1}$ [70]. In the Leucaena species, preliminary observations show that the Tarramba cultivar with seeds originating from Kupang (East Nusa Tenggara Province) and known to be more resistant to pest, has tremendous biomass potential $[71,72]$. For Gliricidia species, the breeding is more on efforts to increase plant productivity, especially as a source of animal feed. This study's results indicate the provenance of Retalhuleu from Guatemala, America, has the highest productivity [73].

The dissemination of superior seeds should be carried out immediately. However, it is still in the development stage to support superior seeds for energy wood in the regions. In each area with the potential to be developed, it can be carried out the construction of seed source plots using seeds from superior individuals so that the distribution of superior material in the fulfillment of superior seeds for energy wood plantation can be immediately fulfilled.

Assistance for superior seedlings to farmers can be given directly in ready-to-plant seedlings or collectively by building a nursery in each region. This program is usually carried out through community nursery activities, managed by a village institution, and integrated with degraded land rehabilitation activities. The government funds the community nursery, and the seedlings produced are used for planting as part of community empowerment in forest and land rehabilitation activities.

Apart from using superior seedlings, the priority scenario selected in the degraded land rehabilitation model also emphasizes the increase in forestry extension effectiveness in assisting the community. Assistance is carried out to foster the community's ability and creativity by learning together to independently sustainably manage the stand to improve their welfare [74]. Through extension agents' mentoring activities, farmers will be motivated to use superior seedlings and apply intensive maintenance to increase plant productivity.

The minimal number of civil service extension appointments, coupled with the age of forestry extension officers approaching retirement age, is a major obstacle in increasing the effectiveness of extension in the regions. On the other hand, the Ministry of Environment and Forestry is implementing a program to provide access to forest management covering 12.7 million hectares for the community, so it is necessary to have assistants at the site level. To minimize the impact, the Government optimizes community self-help extension recruited as civil servant extension partners. They are generally the chairperson/ administrator of farmer groups who have succeeded in the forestry business or community leaders who have become role models. As residents who live with the community, they easily mingle with the community and do not need to pay extra for housing and other things than bringing in personnel from outside the area.

\section{Conclusions}

The model of degraded land rehabilitation through the development of energy wood plantations in East Lombok Regency was built from the biophysical, social, and economic subsystems. The model was used to 
simulate the conditions in the next 20 years based on existing conditions and three alternative scenarios for the development policies of energy wood plantations. In the biophysical subsystem, the simulation shows that planting energy wood plantations on degraded land using Acacia, Gliricidia, Calliandra, or Leucaena species in all scenarios will reduce the degraded land area by $16 \%$. This decline is in line with the development of quite extensive energy wood plantations in 2040. As the area of plantations increases through rehabilitation of degraded land each year, energy wood production will also increase so that in 2040.

In the social subsystem, rehabilitation of degraded land into energy plantations can reduce the number of unemployed by half the simulated amount, while applying a moderate, optimistic, or very optimistic scenario, the number of unemployed will only be a quarter left in 2040. In the economic subsystem, the very optimistic scenario will produce the highest sales value compared to the existing condition. Based on the achievement analysis of the objective variables in each scenario and the consideration of the risk of failure, the optimistic scenario was considered to be applied in the rehabilitation of degraded land. To achieve the expected goals in this scenario, the implementation of critical land rehabilitation must be supported by the use of superior seedlings and effective forestry extension by increasing the number of extension officers and extension assistants.

\section{Acknowledgements}

The authors would like to acknowledge all those who have helped fulfill the data, information, and permits required in this research. The authors declare that the main contributor in this article is BHN.

\section{Conflict of Interest}

The authors declare no conflict of interest.

\section{References}

1. STATISTICS INDONESIA. Statistical Yearbook of Indonesia. BPS-Statistics Indonesia: Jakarta, Indonesia, 758, 2021.

2. MINISTRY OF ENERGY AND MINERAL RESOURCES. Handbook of Energy \& Economic Statistics of Indonesia. Center for Data and Information Technology on Energy and Mineral Resources: Jakarta, Indonesia, pp. 129, 2020.

3. ZHAO S., DUAN Y., CHEN L., LI Y., YAO T., LIU S., LIU M., LU J. Study on emission of hazardous trace elements in a $350 \mathrm{MW}$ coal-fired power plant. Environ. Pollut., 226, 404, 2017.

4. MINICHILli F., GORINI F., BUSTAFFA E., CORI L., BIANCHI F. Mortality and hospitalization associated to emissions of a coal power plant: A population-based cohort study. Sci. Total Environ., 694, 133757, 2019.

5. DANISH ENERGY AGENCY. Lombok Energy Outlook. Danish Energy Agency and Energy Analyses: Copenhagen, Denmark, 52, 2018.

6. ZAMBELLI P., LORA C., SPINELLI R., TATTONI C., VITTI A., ZATELLI P., CIOLLI M. A GIS decision support system for regional forest management to assess biomass availability for renewable energy production. Environ. Model Softw., 38, 203, 2012.

7. PÉREZ L.E.A., VEGA M., RODRÍGUEZ L.C., FLORES M., ZAROR C.A., LEDÓN Y.C. Life-Cycle Assessment of coal-biomass based electricity in Chile: Focus on using raw vs torrefied wood. Energy Sustain. Dev., 29, 81, 2015.

8. LOEFFLER D., ANDERSON N. Emissions tradeoffs associated with co-firing forest biomass with coal: A case study in Colorado, USA. Appl. Energy, 113, 67, 2014.

9. NDOU N.R., BADAA S.O., FALCONA R.M.S., WEIERSBYE I.M. Co-combustion of Searsia lancea and Tamarix usneoides with high ash coal. Fuel, 267, 1172, 2020.

10. LI J., BRZDEKIEWICZ A., YANG W., BLASIAK W. Co-firing based on biomass torrefaction in a pulverized coal boiler with aim of $100 \%$ fuel switching. Appl. Energy, 99, 344, 2012.

11. LEE S.M., KIM Y., JAUNG W., LATIFAH S., AFIFI M., FISHER L.A. Forests, fuelwood and livelihoods-energy transition patterns in eastern Indonesia. Energy Policy, 85, 61, 2015.

12. BAE J.S., KIM C., KIM Y.S., LATIFAH S., AFIFI M., FISHER L.A., LEE S.M., KIM I.A., KANG J., KIM R., KIM J.S. Opportunities for Implementing REDD+ to Enhance Sustainable Forest Management and Improve Livelihoods in Lombok, NTB, Indonesia. CIFOR: Bogor, Indonesia, 151, 2014.

13. NARENDRA B.H., WIDIATMAKA, KUSMANA C., KARLINASARI L., MACHFUD. Critical land mapping for the development of biomass-based energy in East Lombok Regency, Indonesia. IOP Conf. Series: Earth and Environmental Science, 314, 012072, 2019.

14. NARENDRA B.H., WIDIATMAKA, KUSMANA C., KARLINASARI L., MACHFUD. Assessment of critical land potency for energy plantation forest development in East Lombok. Jurnal Penelitian Hutan dan Konservasi Alam, 16 (2), 119, 2019 [In Indonesia].

15. MARANDURE T., DZAMA K., BENNETT J., MAKOMBE G., MAPIYE K. Application of system dynamics modelling in evaluating sustainability of lowinput ruminant farming systems in Eastern Cape Province, South Africa. Ecol. Model., 438, 109294, 2020.

16. FORRESTER J.W. Industrial Dynamics. The MIT Press, John Wiley and Sons: New York, US, 464, 1961.

17. STERMAN J.D. Business Dynamics: System Thinking and Modelling For Complex World. McGraw Hill: Boston, US, 1008, 2000.

18. AHMADVAND A.M., VARANDI A.N., BASTAN M., YAHYAEI M. Analysis of Tehran construction and demolition waste management with system dynamics approach. Asian Journal of Research in Business Economics and Management, 4 (8), 234, 2014.

19. KHOSHNESHIN F., BASTAN M. Analysis of dynamics of crisis management in the earthquake and performance improvement using system dynamics methodology. 10th International Conference on Industrial Engineering. University of Tehran: Tehran, Iran. 2014. 
20. BASTAN M., DOUST R.M.K, SISI S.D., AHMADVAND A. Sustainable development of agriculture: a system dynamics model. Kybernetes, 4, 1, 2017.

21. ABBASI E., BASTAN M., AHMADVAND A. A system dynamics model for mobile banking adoption. $12^{\text {th }}$ International Conference on Industrial Engineering. Kharazmi University: Tehran, Iran. 2016.

22. HEJAZI T.H., SALMASNIA A., BASTAN M. Optimization of correlated multiple response surfaces with stochastic covariate. International Journal of Computer Theory and Engineering, 5 (2), 341, 2012.

23. WIT M., JUNGINGER M., LENSINK S., LONDO M., FAAIJ A. Competition between biofuels: Modeling technological learning and cost reductions over time. Biomass Bioenergy, 34, 203, 2010.

24. CHANG Y.C., HONG F.W., LEE M.T. A system dynamic based DSS for sustainable coral reef management in Kenting coastal zone, Taiwan. Ecol. Model., 211, 153, 2008

25. BARISA A., ROMAGNOLI F., BLUMBERGA A., BLUMBERGA D. Future biodiesel policy designs and consumption patterns in Latvia: a system dynamics model. J. Clean. Prod. 88, 71, 2015.

26. ESPINOZA A., BAUTISTA S., NARVÁEZ P.C., ALFARO M., CAMARGO M. Sustainability assessment to support governmental biodiesel policy in Colombia: A system dynamics model. J. Clean. Prod., 141, 1145, 2016.

27. MUTINGI M., MBOHWA C., KOMMULA V.P. System dynamics approaches to energy policy modelling and simulation. Energy Procedia, 141, 532, 2017.

28. BLUMBERGA A., BAZBAUERS G., DAVIDSEN P.I., BLUMBERGA D., GRAVELSINS A., PRODANUKS T. System dynamics model of a biotechonomy. J. Clean. Prod., 172, 4018, 2018.

29. SALMASNIA A., BASTAN M., MOEINI A. A robust intelligent framework for multiple response statistical optimization problems based on artificial neural network and Taguchi method. International Journal of Quality, Statistics, and Reliability, 2012, 494818, 2012.

30. BALA B.K., ARSHAD F.M., NOH K.M. System Dynamics Modelling and Simulation. Springer: Singapore, 278, 2017.

31. MUHAMMADI, AMINULLAH E., SUSILO B. Analisis Sistem Dinamis. UMJ Press: Jakarta, Indonesia, 415, 2001 [In Indonesia].

32. SHEN Q., CHEN Q., TANG B., YEUNG S., HU Y., CHEUNG G. A system dynamics model for the sustainable land use planning and development. Habitat International, 33, 15, 2009.

33. FORRESTER J.W., SENGE P. Tests for building confidence in system dynamics models. In System Dynamics; Legasto A.A., Forrester J.W., Lyneis T.M., Eds., Elsevier: New York, US, 1980.

34. BARLAS Y. Formal aspect of model validity and validation in system dynamics. Syst. Dyn. Rev., 12 (3), 183, 1996

35. MINISTRY OF ENVIRONMENT AND FORESTRY. Road map for sustainable development goals 2018-2030. Ministry of Environment and Forestry: Jakarta, Indonesia, 179, 2018.

36. SINGH B., DHILLON G.P.S., GILL R.I.S., KAUR J. Biomass Production of High Density Leucaena leucocephala Plantation under different levels of nutrients. The Indian Forester, 145 (1), 34, 2019.

37. CHOTCHUTIMA S., KANGVANSAICHOL K., TUDSRI S., SRIPICHITT P. Effect of spacing on growth, biomass yield and quality of Leucaena (Leucaena leucocephala (Lam.) de Wit.) for renewable energy in Thailand. J. Sustain. Bioenergy Syst., 3, 48, 2013.

38. HENDRATI R.L. Genetic improvement of Calliandra calothyrsus for qualified wood energy. In Proceedings of International Conference of Indonesia Forestry Researchers III; Siregar C.A., Pratiwi, Mindawati N., Eds., Research Development and Inovation Agency: Bogor, Indonesia, 2016.

39. COOK B.G., SCHULTZE-KRAFT R., PENGELLY B.C., TAYLOR M., JONES C., BURKART S., PETERS M. Tropical Forages: an interactive selection tool. CIAT and ILRI: Montpellier, France, 2019.

40. SHELTON H.M. Tropical forage tree legumes in agroforestry systems. Unasylva, 51 (200), 25, 2000.

41. MACEDO M.O., RESENDE A.S., GARCIA P.C., BODDEY R.M., JANTALIA C.P., URQUIAGA S., CAMPELLO E.F.C., FRANCO A.A. Changes soil $\mathrm{C}$ and $\mathrm{N}$ stocks and nutrient dynamics 13 years after recovery of degraded land using leguminous nitrogen-fixing trees. For. Ecol. Manage., 255 (5), 1516, 2008.

42. DUBIEZ E., FREYCON V., MARIEN J., PELTIER R., HARMAND J. Long term impact of Acacia auriculiformis woodlots growing in rotation with cassava and maize on the carbon and nutrient contents of savannah sandy soils in the humid tropics (Democratic Republic of Congo). Agroforest Syst., 93 (3), 1167, 2018.

43. NARENDRA B.H. Trial of alley cropping system in critical land rehabilitation of pumice mined. Jurnal Penelitian Hutan dan Konservasi Alam. 3 (3), 225, 2006.

44. SIREGAR U.J., NARENDRA B.H., SUWARNA J., SIREGAR C.A., WESTON C. Evaluation on community tree plantation as sustainable source for rural bioenergy in Indonesia. International Conference on Biomass 10-11th October 2016. Surfactant and Bioenergy Research Center: Bogor, Indonesia, 2016.

45. HUDAEDI D., HARIYADI, ANWAR S. The potential of Gliricidia sepium as raw material for biomass power plans (case study: East Manggarai District - East Nusa Tenggara Province). Journal of Env. Engineering \& Waste Management, 3 (1), 13, 2018.

46. NARENDRA B.H. Effects of mycorrhiza on early growth of Calliandra calothyrsus on critical land of former Batur Volcanic Eruption. In Mycorrhiza: biological fertilizers and pesticides that support environmentally friendly sustainable agriculture. Lampung University: Bandar Lampung, Indonesia, 2011.

47. NARENDRA B.H. The Effect of soil condition improvement on Calliandra calothyrsus and Antidesma bunius growth in Batur Mountain Conservation Area, Bali. Jurnal Penelitian Hutan dan Konservasi Alam, 9 (2), 101, 2012 [In Indonesia].

48. WOOD S.R., DENT F.J. LECS: A Land Evaluation Computer System Methodology, Manual 5: Methodology. Centre for Soil Research, Ministry of Agriculture: Bogor, Indonesia, pp.221, 1983.

49. FOOD AND AGRICULTURE ORGANIZATION. A framework for land evaluation. FAO Soil Bulletin, no. 32, FAO: Rome, Italy, 1976.

50. DRAJAT, BUSTOMI S., WIDODO S., MINDAWATI N., ROSTIWATI T., KOSASIH A.S., WIDIARTI A., KUSMIADI E., SIREGAR A.N., HERYATI Y. The technical design of planting with an intensive silviculture system. Forest Plant Germination Center: Bandung, Indonesia, 108, 2006. 
51. LEKSONO B. Intensive silviculture for energy plantation development. In addressing climate change for the preservation of forest resources and the economy of biological resources; Diana R., Sulistioadi Y.B., Karyati, Eds., Mulawarman University: Samarinda, Indonesia, 2017.

52. WIYONO, LESTARI P., HIDAYAT R., OKTALINA S.N., UTOMO S., PRASETYO E., NGADIANTO A., NUGROHO P. Application of Intensive Silvicultural Techniques in Community Forest Management in Gunungkidul Regency. Jurnal Pengabdian dan Pengembangan Masyarakat, 1 (1), 57, 2018.

53. SARGENT R.G. Verification and validation of simulation models. In Proceedings of the 1998 Winter Simulation Conference; Medeiros D.J., Watson E.F., Carson J.S., Manivannan M.S., Eds., IEEE: Washington, USA, 1998.

54. HERRY B., MACHFUD, MARIMIN, HERMAWAN A., WIYONO E.S. The prediction model for indicators of sustainability of dry anchovies agro-industry resources uses a dynamic system. Agrointek, 5 (2), 67, 2011.

55. BYRNE R.F. Beyond Traditional Time-Series: Using Demand Sensing to Improve Forecasts in Volatile Times. J. Bus. Forecast., 31 (2), 13, 2012.

56. KIM S., KIM H. A new metric of absolute percentage error for intermittent demand forecasts. Int. J. Forecast., 32, 669, 2016.

57. FEATHERSTON C.R., DOOLAN M. Using system dynamics to inform scenario planning: a case study. In the $31^{\text {st }}$ International Conference of the System Dynamics Society. System Dynamics Society: Littleton, USA, 2013.

58. COZZI M., VICCARO M., NAPOLI F.D., FAGARAZZI C., TIRINNANZI A., ROMANO S. A spatial analysis model to assess the feasibility of short rotation forestry fertigated with urban wastewater: Basilicata region case study. Agric. Water Manag., 159, 185, 2015.

59. PUSPITOJATI T., MILE M.Y., FAUZIAH E., DARUSMAN D. Community Forest Contribution of Rural Communities to Plantation Forests. Kanisius: Yogyakarta, Indonesia, 102, 2014.

60. SASTROAMIDJOJO J.S. Acacia auriculiformis, Melaleuca leucadendron. Gadjah Mada University: Yogyakarta, Indonesia, 1976.

61. MULYASARI T. Characteristics of Some Wood Species as Biomass Energy Raw Materials. IPB University: Bogor, Indonesia, 2013 [In Indonesia].

62. CAHYONO T.D., COTO Z. FEBRIANTO F. Heat value analysis and economic feasibility of wood utilization as coal substitution in cement factory. Forum Pascasarjana, 31, 105, 2008 [In Indonesia].
63. WOLF J.P., DONG. Biomass combustion for power generation: an introduction. In Biomass Combustion Science, Technology and Engineering; Rosendahl L., Woodhead Publishing: Cambridge, UK, 3, 2013.

64. 64. FUCHS E.F., MASOUM M.A.S. Power Conversion of Renewable Energy Systems. Springer: New York, US, pp.692, 2011.

65. GULTOM T.T. Utilization of photovoltaics as a solar power generator. Dunia Ilmu, 1 (3), 33, 2015 [In Indonesia].

66. SANTOSO H. Optimization to produce the ideal efficiency of a $20 \mathrm{MW}$ biomass power generator steam turbine. String, 3 (2), 181, 2018.

67. AKHDIYATUL, RADWITYA E., CHANDRA Y. Technical and economic analysis in the use of biomass fuel in a steam power plant. Elkha, 10 (2), 49, 2018.

68. GONÇALVES A.C., MALICO I., SOUSA A.M.O. Solid Biomass from Forest Trees to Energy: A Review. In Renewable Resources and Biorefineries; Jacob-Lopes E., Zepka L.Q., Eds., Intech Open: London, UK, 2018.

69. SCHMIDT L. Guidelines for handling tropical and subtropical forest plant seeds. Ministry of Forestry: Jakarta, Indonesia, 530, 2002.

70. HENDRATI R.L. Development of superior plants for energy wood raw materials. Centre for Forest Biotechnology and Tree Improvement: Yogyakarta, Indonesia, 2019.

71. HENDRATI R.L., NURROHMAH S.H. Genetic improvement of Leucaena leucocephala for wood energy. Tropical Grasslands-Forrajes Tropicales, 7 (2), 210, 2019.

72. RENGSIRIKUL K., KANJANAKUHA A., ISHII Y., KANGVANSAICHOL K., SRIPICHITT P., PUNSUVON V., VAITHANOMSAT P., NAKAMANEE G., TUDSRI S. Potential forage and biomass production of newly introduced varieties of leucaena (Leucaena leucocephala (Lam.) de Wit.) in Thailand. Grassland Science, 57, 94, 2011.

73. PUGER A.W., SUBERATA I.W., PUTRA I.G.E., SUARNA I.M., NITIS I.M. Gamal seed evaluation of Retalhuleu provenance on dry land in Bukit Badung Bali. Pastura, 1 (1), 16, 2011 [In Indonesia].

74. LARASATI F.A., QURNIATI R., HERWANTI S. The role of community forestry extension officers in helping communities to obtain community forest permits in Sendang Agung Subdistrict, Central Lampung Regency. Jurnal Ilmu Pertanian Indonesia, 20 (1), 9, 2015 [In Indonesia]. 